\title{
Lusioersily
}

\section{Anonymity, Irish Women's Writing, and a Tale of Contested Authorship: Blue-Stocking Hall (1827) and Tales of my Time (1829)}

Byrne, A. (2019). Anonymity, Irish Women's Writing, and a Tale of Contested Authorship: Blue-Stocking Hall (1827) and Tales of my Time (1829). Proceedings of the Royal Irish Academy Section C: Archaeology, Celtic Studies, History, Linguistics and Literature, 119, 259-281. https://doi.org/10.3318/PRIAC.2019.119.02

Link to publication record in Ulster University Research Portal

\section{Published in:}

Proceedings of the Royal Irish Academy Section C: Archaeology, Celtic Studies, History, Linguistics and Literature

\section{Publication Status:}

Published (in print/issue): 27/02/2019

DOI:

10.3318/PRIAC.2019.119.02

\section{Document Version}

Author Accepted version

\section{General rights}

Copyright for the publications made accessible via Ulster University's Research Portal is retained by the author(s) and / or other copyright owners and it is a condition of accessing these publications that users recognise and abide by the legal requirements associated with these rights.

\section{Take down policy}

The Research Portal is Ulster University's institutional repository that provides access to Ulster's research outputs. Every effort has been made to ensure that content in the Research Portal does not infringe any person's rights, or applicable UK laws. If you discover content in the Research Portal that you believe breaches copyright or violates any law, please contact pure-support@ulster.ac.uk. 


\title{
Anonymity, Irish women's writing, and a tale of contested authorship: Blue stocking hall (1827) and Tales of my time (1829)
}

\author{
Angela BYRne* \\ Ulster University
}

[Accepted 02 January 2019. Published 27 February 2019]

\section{Abstract}

Introduction

*Author's email: byrne.at@gmail.com

ORCID iD: https://orcid.org/0000-0002-2549-8939

doi: https://doi.org/10.3318/PRIAC.2019.119.02

Thanks to Dr Katherine Byrne for her helpful comments on an earlier draft, and to the two anonymous readers whose suggestions improved the paper. This research was supported by an Anna Parnell Travel Grant from the Women's History Association of Ireland in 2017.

${ }^{1}$ Women's anonymous publishing and 'modesty' have both been well covered in scholarship. For example, Carol Pal shows how, in the seventeenth century, Christian modestia was 'the public performance of a woman's virtue' (Republic of women: rethinking the republic of letters in the seventeenth century (Cambridge, 2012), 8). Noah Heringman has shown how women professed 'geological modesty' in nineteenth-century science writing (Romantic rocks, aesthetic geology (Ithaca, NY, 2004), 277). 
Blue stocking hall, Tales of my time, and Irish romanticism sought to identify the 'Lady of great talents and eminent piety' who had graced the public with a work that 'every mother should possess, and every daughter should read'. ${ }^{2}$ Reviews and advertisements in contemporary newspapers indicated that, at the time of publication, it was widely known that the author was a woman, and in 1839 the Irish antiquary John Windele maintained in print that the author was 'Miss Chetwood' - Anna Maria Chetwood (1774-1870). Despite this, the novels were attributed to the English Unitarian minister William Pitt Scargill for more than a century and a half. This remained the case until the late 1990s, when Rolf Loeber and Magda Stouthamer-Loeber reopened the question, and suggested that Anna Maria Chetwood was the author of the novels. ${ }^{3}$ The attribution has been repeated elsewhere, including the important Database of British Fiction, where the name 'Anne Chetwood' is accompanied by a question mark. ${ }^{4}$ Taking its cue from Loeber and Stouthamer-Loeber's tentative attribution, this paper draws on evidence in private papers and in the archives of Colburn and Bentley's publishing house to demonstrate that, while a case can be made in favour of Chetwood's authorship, there is equally compelling evidence that the author may have been her sister-in-law Alicia Wilmot (c.1776-1860). The existing evidence does not support a positive authorial attribution either way. This paper firstly offers a brief assessment of the novels within the general context of Irish romanticism. It then reconstructs both women's heretofore virtually unknown biographies, and finally considers the evidence for each woman as author of the novels.

The three-volume epistolary novel Blue stocking hall (1827) tells the story of young English gentleman Arthur Howard's conversion from a superficial life of fashion and urban pleasure to a simpler but more fulfilling life at his female cousins' home in rural Co. Kerry. His initial revulsion at finding himself in a nest of 'blues' turns to enchantment as he becomes acquainted with his cousins' gentle learning and their charity towards their poorer neighbours. The novel reflects on women's education and the proper uses of knowledge, female friendship, and urban (English) misconceptions of rural (Irish) life. Tales of my time (1829) is a three-volume work comprising two novels: Who is she? and The young reformers. The first claims to be loosely based on real events and relates the fate of Zorilda, bought from Gypsies as a companion for the child Algernon Hartland. As the girl grows into a remarkable beauty, Algernon's mother begins to revoke her former affection for her, emphasising her social inferiority, while Algernon announces his intention to marry her before

\footnotetext{
2 Morning Chronicle, 6 November 1827; Cheltenham Chronicle, 21 January 1830.

3 Rolf Loeber and Magda Stouthamer-Loeber, Irish 18th-19th Century Fiction Newsletter 1 (privately published, January 1998); Rolf Loeber and Magda Stouthamer-Loeber, A guide to Irish fiction 1650-1900 (Dublin, 2004), 268-70.

4 'British fiction, 1800-1829: a database of production, circulation and reception' project website, http://www.british-fiction.cf.ac.uk (accessed 28 October 2018).
} 
being whisked off on a Continental tour. Meanwhile, the former family tutor, Mr Playfair, learns the true story of Zorilda's noble origins, and the tale ends in Algernon's death by fever. The young reformers is the story of Albert, son of a Church of Ireland minister, who becomes radicalised by republican neighbours. To distance him from the United Irishmen, his parents dispatch him to Quebec; he later travels to France and is disappointed on meeting well-known republicans there. He retires to Ireland, where he dedicates himself to peaceful reform. Like Edgeworth's The absentee and Mosse's The old Irish baronet, overseas travel functions in The young reformers as an opportunity for reimagining reform in Ireland. ${ }^{5}$

It is no small irony that Blue stocking hall was published anonymously, given the book's arguments in defence of women's learning. This was not an unusual choice, but in the period 1780-1820 the number of Irish woman authors increased, and the use of pseudonyms decreased. ${ }^{6}$ The 1820 s saw a revival in anonymity, accounting for over 68 per cent of new novels published in Britain and Ireland, and a 'greater reluctance' by women authors to assign their name to a novel; furthermore, Colburn's encouraged anonymity in the 1820 s to cultivate an aura of mystery around its authors. ${ }^{7}$ It has been suggested that middle-class women in the nineteenth century were more likely than men to use a pseudonym because of the stigma attached to earning a living. ${ }^{8}$ In her study of Victorian women's journalism, Alexis Easley argues that anonymous authorship allowed women to tackle themes that were perhaps considered more suitable for male writers, and to overcome the lack of authority commonly associated with the female voice. Crucially, the author of these two novels was not anonymous within her circle; Blue stocking hall was directly referenced in the private correspondence of one of the likely authors. It is worth bearing in mind Stephanie Eckroth's observation that in the period 1790-1823, 'literary circles were small, and readers or reviewers often knew who wrote an anonymous or pseudonymous text', and that similarly, signing a title page as 'by the author of' 'often offered

\footnotetext{
${ }^{5}$ Christina Morin, "At a distance from [my] country": Henrietta Rouvière Mosse, the Minerva Press, and the negotiation of Irishness in the romantic literary marketplace', European Romantic Review 28:4 (2017), 447-60: 455.

${ }^{6}$ Alexis Easley, First person anonymous: women writers and the Victorian print media, 1830-70 (Burlington, VT, 2004); Gerardine Meaney, Mary O'Dowd, and Bernadette Whelan, Reading the Irish woman: studies in cultural encounter and exchange, 1714-1960 (Liverpool, 2013), 71.

7 James Raven, 'The anonymous novel in Britain and Ireland, 1750-1830', in Robert J. Griffin (ed.), The faces of anonymity: anonymous and pseudonymous publication from the sixteenth to the twentieth century (New York, 2003), 141-66: 151, 159, 164. See also Hilary Havens, 'Introduction', in Hilary Havens (ed.), Didactic novels and British women's writing, 1790-1820 (New York, 2017), 1-20.

8 Katherine Bode, 'Thousands of titles without authors: digitized newspapers, serial fiction, and the challenges of anonymity', Book History 19 (2016), 284-316: 313, note 46.
} 
writers no real concealment' and could function effectively as a 'marketing tool' to help boost sales of multiple works. ${ }^{9}$

Valued in their time as didactic (Blue stocking hall in particular), the history of these novels offers a case study in misattribution and the ease with which writing women's voices have been silenced. Disentangling the long history of their misattribution provides insights into the character of the Irish literary diaspora (authors were drawn to Britain partly due to the lack of a thriving literary scene in Ireland) and middle-ranking women's mobility in the nineteenth century, inviting consideration of the ways in which Ireland was written onto the British literary scene. ${ }^{10}$ The novels were written by an Irish-born woman, possibly living in England, and communicate the concerns in Irish romanticism as distinct from — even if occasionally intersecting with—British romanticism. ${ }^{11}$

Blue stocking hall merits consideration for inclusion in Irish romanticism more broadly. Irish romanticism was to a large extent defined by its occupation with national concerns. ${ }^{12}$ Most obviously, Blue stocking hall bears a resemblance to Sydney Owenson's popular novel and foundational text in the Irish 'national tale' genre, The wild Irish girl. ${ }^{13}$ First published in 1806, The wild Irish girl is, like Blue stocking hall, an epistolary novel that relates the story of the personal relationship between an Irish woman and an English man as an optimistic representation of the possibility of a tranquil union between Ireland and Britain. ${ }^{14}$ Blue stocking hall also, like other national tales, embodied the response to the English tour of Ireland. The author is certainly alert to what Claire Connolly

\footnotetext{
${ }^{9}$ Stephanie Eckroth, 'Celebrity and anonymity in the Monthly Review's notices of nineteenth-century novels', in Ann R. Hawkins and Maura Ives (eds), Women writers and the artifacts of celebrity in the long nineteenth century (Farnham, 2012), 13-31.

${ }^{10}$ The role of a self-conscious mobility in romantic expressions of Irishness is examined in Morin, "At a distance from [my] country", and in Julia M. Wright, Representing the national landscape in Irish romanticism (Syracuse, NY, 2014).

${ }^{11}$ See Julia M. Wright, 'Irish romanticism: "whence and what are ye?", European Romantic Review 28:4 (2017), 421-30: 424.

${ }^{12}$ Murray Pittock isolates five distinctive aspects of Irish (and Scottish) romanticism, one of which was 'the inflection of genre towards a distinctively national agenda of selfhood' (Scottish and Irish romanticism (Oxford, 2008), 7), but also argues throughout his book for a recovery of Irish and Scottish romanticism, as of central importance to romantic cultural expression as a whole.

${ }^{13}$ Katie Trumpener, Bardic nationalism: the romantic novel and the British Empire (Princeton, NJ, 1997), 141.

${ }^{14}$ For in-depth analyses of The wild Irish girl, see Elmer Andrews, 'Aesthetics, politics and identity: Lady Morgan's “The wild Irish girl”, Canadian Journal of Irish Studies 13:2 (1987), 7-19; Ina Ferris, 'Narrating cultural encounter: Lady Morgan and the Irish national tale', Nineteenth-Century Literature 51:3 (1996), 287-303; Katja Jylkka, 'Ut pictura poesis? Art and the Irish nation in "The wild Irish girl"', New Hibernia Review / Iris Éireannach Nua 15:3 (2011), 80-93. See also Christina Morin, "Gothic" and "national"? Challenging the formal distinctions of Irish romantic fiction', in Jim Kelly (ed.), Ireland and romanticism: publics, nations and scenes of cultural production (New York, 2011), 172-87.
} 
calls 'the politics of representation' and, partly true to the national tale's blending of presentism and antiquarianism, approaches the problems of representation through contemporary themes. ${ }^{15}$ It is clear in Blue stocking hall that she is aware of English readers' predominantly negative perceptions of Ireland, and indeed, it is clear that she is well acquainted with both countries. The following extract illustrates how the novel plays on those negative stereotypes to produce a critique of the English traveller who sought an imagined 'savagery'. It appertains to a letter Blue stocking hall's male protagonist, Arthur Howard, receives from his sister in London, in which she informs him of the travel plans of two of his friends:

Russell, and that blockhead Annesley, are gone to see Killarney, the Giant's Causeway, and whatever other odds and ends, in the way of lionizing that savage island may offer. Now, if they poke you out from the hole in which you are buried, or stumble upon you in a bog, the ass, alias Annesley, will begin to bray [...]. ${ }^{16}$

Indeed, on Howard's arrival in Kerry, he writes to his friend, Falkland:

After a journey through a horrible country, as naked as if it was but just born, and as comfortless as if it had never been inhabited [...] You must not expect me to name places which I cannot spell, nor jolt over such roads as I have escaped again with you. [...] Candour obliges me to confess, that nothing in nature can exceed the scenery of this spot when once you are at it; [...] Part of my way lay through a morass, technically called bog in this country, which brought to my recollection every frightful engulfment that I ever heard or read of. (I: 20-1)

Later, in a sub-plot, Howard encounters acquaintances making a whistle-stop tour of southern Ireland. Lady Matilda tells him of her Irish tour: 'I never was so weary in my life; and am so frightened too, since I came into this barbarous country, that I do not attempt to sleep, though I make two of the servants sit up every night with loaded arms to repel an attack. It is more than my nerves can endure [...]' (II: 163). This is the first mention of any threat of violence, and it appears incongruous, an outdated idea. Shortly afterwards, Howard himself reproduces the stock imagery of the Killarney region, in a sensible appreciation of the picturesque and sublime (II: 181). It is significant that Howard travels to Kerry; first, it was a place famed since the 1750 s as a destination for the picturesque tourist, and still operated as a wild fringe of Britain in the late $1820 \mathrm{~s} ;{ }^{17}$ secondly, it was a place with which the author was likely familiar,

${ }_{15}$ Claire Connolly, A cultural history of the Irish novel, 1790-1829 (Cambridge, 2012), 1. See also Ina Ferris, The romantic national tale and the question of Ireland (Cambridge, 2002); Trumpener, Bardic nationalism.

${ }^{16}$ Blue stocking hall (London, 1827), II: 95. Italics in original. Hereafter, references to the book are given as in-line citations.

${ }^{17}$ See Luke Gibbons, 'Topographies of terror: Killarney and the politics of the sublime', South Atlantic Quarterly 95 (1996), 23-44. 
at least enough to give voice to the young Englishman's initially critical assessment; and finally, Howard could then be all the more surprised to find in this wild fringe a spot in which learning thrived, and one that supported the cultivation of the higher expressions of the human spirit.

How can we read Blue stocking hall's representation of Ireland? Ina Ferris, drawing on Paul Magnuson's concept of 'public Romanticism', has demonstrated how Ireland simultaneously functioned as 'an actor within the domestic literary field' and as a part of colonial romanticism. ${ }^{18}$ While the two families under investigation here, the Chetwoods and Wilmots, had no fixed long-term centre, with the circle revolving around individual members rather than particular locations or homes, they were very much 'of Ireland' and in their relocation to Britain can be understood in the context of the Irish literary diaspora of the period. So, too, are the novels Blue stocking hall and Tales of my time 'of Ireland'. Both tales, to a lesser or greater degree, are set in Ireland or among Irish communities, and are concerned with Irish themes or with representing a positive image of Ireland for an English readership against the backdrop of O'Connellite politics and Catholic Emancipation. Set in rural County Kerry, Blue stocking hall is alert to two main issues: the ways in which women's learning was belittled when the 'Blue' was made a figure of fun and of derision; and the similar functioning of English attitudes towards Ireland. ${ }^{19}$ It is notable that these attitudes are identifiable in Chetwood-Wilmot private correspondence, such as when Martha Wilmot parodied the Irish brogue in her Russian letters: '[...] as Paddy does when he says, "Plaise your honour's honour". ${ }^{20}$ The author does, however, defend women's scholarship when Blue stocking hall's protagonist is recommended to read Charlotte Eaton's acclaimed Rome in the nineteenth century (1820), as 'this work of a female pen [is] by a thousand degrees the best vade mecum with which you can furnish yourself' (I: 304).

The ways in which members of the Chetwood-Wilmot circle engaged with Irish romanticism are further evident in their manuscript albums, especially in Anna Maria Chetwood's unpublished but privately circulated elegy to Robert Emmet. Standing as a monument to the friendship between members of the circle and Sarah Curran, it also embodies the exploration of the relationship between

${ }^{18}$ Ferris, The romantic national tale and the question of Ireland, 2-3; Paul Magnuson, Reading public romanticism (Princeton, NJ, 1998).

${ }^{19}$ See Gibbons, 'Topographies of terror'; Glenn Hooper, 'The Isles/Ireland: the wilder shore', in Peter Hulme and Tim Youngs (eds), The Cambridge companion to travel writing (Cambridge, 2002), 174-90; Glenn Hooper, Travel writing and Ireland, 1760-1860: culture, history, politics (Houndmills, 2005); William H.A. Williams, Tourism, landscape, and the Irish character: British travel writers in pre-famine Ireland (Madison, WI, 2008); William H.A. Williams, Creating Irish tourism: the first century, 1750-1850 (London, 2011).

${ }^{20}$ Martha Wilmot to her mother, 24 April 1804, in H. Montgomery Hyde and Edith Stewart (eds), The Russian journals of Martha and Catherine Wilmot: being an account by two Irish ladies of their adventures in Russia as guests of the celebrated Princess Daschkaw, containing vivid descriptions of contemporary court life and society, and lively anecdotes of many interesting historical characters 1803-1808 (1934; reprint, New York, 1971), 95. 
the political and the personal that Jim Kelly finds at the heart of Irish romanticism. ${ }^{21}$ Curran was exiled from her parents' Dublin home for her affair with Emmet, following his execution for treason in 1803. She subsequently resided at Cooper Penrose's home at Woodhill, Co. Cork, ${ }^{22}$ and it is likely that it was during this time that she became part of the Chetwood-Wilmot circle. Curran's repeated reference to Katherine Wilmot, Anna Maria Chetwood, Anne Latham, and Margaret King, Lady Mount Cashell in her surviving letters to Anne Penrose, her closest friend, indicate a strong network and a close group dynamic. ${ }^{23}$ The connections between the Chetwoods and Curran were further solidified when Anna Maria Chetwood's father, Rev. John Chetwood, officiated at Curran's marriage to Captain Sturgeon in 1805. The esteem in which Curran was held within the circle is finally evidenced in Rev. Chetwood's composition of an epitaph on her untimely death in $1808 .{ }^{24}$ These connections have obvious implications for the Wilmot and Chetwood women's political identities, the complexity of which is reflected in their responses to Emmet's execution and Irish romanticism. ${ }^{25}$

It is, finally, worth noting that the Wilmots transcribed lines from James Macpherson's 'Ossian poems'- significantly, one of the foundation texts of Irish and Scottish romanticism - and an English translation of the Irish ballad 'Cushla [cuisle] mo chroi' ('Pulse of my heart'). ${ }^{26}$ They also transcribed the popular songs 'Oh the rogue! Or, Beau Napperty's garland', composed during the 1798 rebellion, and 'Croppy's lamentation, or French fidelity'. ${ }^{27}$ In Blue

21 Jim Kelly, 'Introduction', in Kelly, Ireland and romanticism, 3-4. Harriet Kramer Linkin also finds this in Mary Tighe's poetry; see 'Locating Irish romanticism in Mary Tighe's poetry and prose', European Romantic Review, 28:4 (2017), 431-45: 432.

${ }^{22}$ Peter Murray, 'Taste and sensibility: the patronage of Cooper Penrose', Irish Arts Review (autumn 2006), 110-15; Frances Clarke and Sylvie Kleinman, 'Curran, Sarah', in James McGuire and James Quinn (eds), Dictionary of Irish Biography (hereafter DIB) (Cambridge, 2009), online edition, available at: http://dib.cambridge.org/viewReadPage. do? articleId=a2323 (accessed 16 January 2019).

${ }^{23}$ NLI, MS 8327, Sarah Curran (Mrs Sturgeon), Letters written from the Mediterranean coast and England, 1806-8. See also Ellen Gill, Naval families, war and duty in Britain, 1740-1820 (Woodbridge, 2016), 155-60, and Patrick M. Geoghegan, Robert Emmet: a life (Dublin, 2002), 30-7.

${ }^{24}$ The epitaph was intended for her tombstone, but this plan was never realised. It was published in William Maziere Brady (ed.), Clerical and parochial records of Cork, Cloyne, and Ross (3 vols, London, 1864), I: 53.

${ }^{25}$ For a consideration of what constituted 'Irish romanticism', see Pittock, Scottish and Irish romanticism.

26 James Macpherson, Fragments of ancient poetry, collected in the Highlands of Scotland, and translated from the Galic or Erse language (Edinburgh, 1760); Pittock, Scottish and Irish romanticism, 17.

27 'Beau Napperty' was Napoleon Bonaparte. See Georges Denis Zimmerman, Songs of Irish rebellion: Irish political street ballads and rebel songs, 1780-1900 (2nd ed., Dublin, 2002). On cultural 'Irishness' in eighteenth-century Ireland, see Toby Barnard, "'Grand metropolis" or "The anus of the world"? The cultural life of eighteenth-century Dublin', in Peter Clark and Raymond Gillespie (eds), Two capitals (Oxford, 2001), 185-210. 
stocking hall, the protagonist's young cousin is found to have collected Gaelic folksongs in the mountains of Kerry. The author may have been inspired by Martha Wilmot's collection and translation of Russian folksong during her five years in Russia, if not by the more obvious 'Ossian poems' recorded in the Wilmot albums. ${ }^{28}$ As if to demonstrate the intellectual validity and scholarliness of these activities, and their value as cultural artefacts, Howard's cousin's Gaelic folksongs are followed almost immediately by a reference to a 'deathsong' published in Thomas Crofton Croker's 1824 volume Researches in the south of Ireland (II: 87-9). ${ }^{29}$

The lives of Anna Maria Chetwood and Alicia Wilmot
The Wilmot and Chetwood families were closely connected by friendship and by marriage. The ties between these two middle-ranking, Cork-based families were formed when Captain Edward Wilmot and his wife Martha (née Moore) moved from Drogheda, Co. Louth, to Glanmire, Co. Cork in the 1770s. The local Church of Ireland rector was John Chetwood (1742-1814) of Rathcooney, who lived there with his wife, Elizabeth Hamilton, and their children. The families seem to have quickly become friends, and established enduring intergenerational links that were solidified by the marriage of Robert Wilmot (1772-1815) and Elizabeth Chetwood (b. 1771) in 1798. The nine Wilmot children and the (at least) seven Chetwood children were of similar ages, and some of them remained friends for life. The most interesting members of these families for the purposes of this inquiry are Elizabeth Wilmot (née Chetwood), Alicia Wilmot (c.1776-1860), and Anna Maria Chetwood (1774-1870), who were at the core of a circle of travelling and writing Irish Protestant women. The wider circle also included well-known international 'bluestockings' and political radicals, such as Princess Ekaterina Romanovna Dashkova, Maria Edgeworth, Caroline Hamilton (née Tighe), and Margaret King, Lady Mount Cashell. ${ }^{30}$ Based at first in the environs of Cork city and, later, around English spa towns, the circle demonstrated strong cohesion despite the high level of geographical mobility demonstrated by its members. As will become clear, the close ties of blood and friendship that existed between these women played no small part in the uncertainty that has long surrounded the authorship of the novels Blue stocking hall and Tales of my time.

\footnotetext{
${ }^{28}$ See A.G. Cross, 'Early British acquaintance with Russian popular song and music (the letters and journals of the Wilmot sisters)', Slavonic and East European Review 66:1 (1988), 21-34. The Ossian poems and other transcriptions are at Royal Irish Academy (RIA), MS 12L25, Dashkova and Wilmot [and others], Poems and miscellaneous notes, 1803-7, unpaginated manuscript.

${ }^{29}$ Thomas Crofton Croker, Researches in the south of Ireland (London, 1824), 174-6.

${ }^{30}$ This network is studied in detail in an article in preparation. For more on Irish women's literary networks, see Amy Prendergast, Literary salons across Britain and Ireland in the long eighteenth century (London, 2015).
} 
Anna Maria Chetwood was born on 7 February $1774 .{ }^{31}$ Virtually nothing is known of her early life, but she appears to have been educated by her parentsplacing her among the numerous examples of educated clergymen's daughters of her generation - and there is evidence that she had a lifelong interest in literature. ${ }^{32} \mathrm{~A}$ selection of her poems is found among the Wilmot papers (in the Royal Irish Academy and Senate House Library) and it is quite likely that she was the 'Miss Chetwood' of Glanmire listed among the subscribers to a poetry volume in 1808. ${ }^{33}$ Loeber and Stouthamer-Loeber state that Chetwood resided at Glanmire until at least $1821 .{ }^{34}$ She may have moved to Woodbrook, Portarlington sometime in the 1820s, on at least a part-time basis. Given the scarcity of information relating to her whereabouts between 1821 and 1833, it is possible that she lived at Woodbrook as a carer for her elderly and childless uncle and his wife. ${ }^{35}$ A reference in a regional newspaper to her travelling to Ireland in 1833 indicates that she had moved to Cheltenham by that date. ${ }^{36}$ She remained there for the rest

${ }^{31}$ National Library of Ireland (NLI), Genealogical Office MS 174, 109-11, Pedigree of Chetwode of Woodbrook in Queen's Co. \& Glanmire, Co. Cork and Wilmot of Woodbrook, later Chetwode, $c$. 1570-1837. Rev. Chetwood's death was announced, 'in his 76th year', in the Gentleman's Magazine 84, pt 2 (August 1814), 196.

32 On the pastoral motivations for Anglican clerical support for women writers, see Susan Staves, 'Church of England clergy and women writers', Huntington Library Quarterly special issue: Reconsidering the Bluestockings 65:1-2 (2002), 81-103.

${ }_{33}$ RIA, Wilmot papers, MS 12L25, Ekaterina Romanovna Dashkova and Martha Wilmot [and others], Poems and miscellaneous notes, 1803-7; Senate House Library, University of London, MS 704, Commonplace book [...] containing copies of poems by various authors, including Mrs R. Wilmot, Rev. John Chetwood, and Edward Wilmot [early 19th century]; Felicia Dorothea Browne, Poems (Liverpool, 1808). It is worth suggesting that Chetwood and Browne may have been acquainted, as Browne's paternal grandfather was George Browne of Passage, Co. Cork (Nanora Sweet, 'Hemans [née Browne], Felicia Dorothea', Oxford Dictionary of National Biography (hereafter ODNB), available at: https:// doi.org/10.1093/ref:odnb/12888 (accessed 14 January 2019)). This volume of poems, written when Browne was aged 8-13 years (as explained in the preface), bears a similar thematic focus to the unpublished Wilmot-Chetwood compositions: poems in praise of nature, dedications on friends' birthdays, and epitaphs for friends and family.

${ }^{34}$ Magda Loeber and Rolf Loeber, 'Chetwode (Chetwood), Miss (Anna Maria?)', in James McGuire and James Quinn (eds), DIB (Cambridge, 2009), online edition, available at: http://dib.cambridge.org/viewReadPage.do?articleId=a1639 (accessed 16 January 2019).

${ }^{35}$ Jonathan Chetwood (1757-1839), high-sheriff of Queen's County, and Margaret, daughter of Lawrence Clutterbuck of Derryluskon, Co. Tipperary; they married in 1781 and had no issue; see John Bernard Burke, A genealogical and heraldic dictionary of the landed gentry of Great Britain and Ireland (London, 1847), I: 213. Anna Maria Chetwood never married (Western Daily Press, 27 December 1870).

${ }_{36}$ The Looker-On, 28 Aug. 1833; The Cheltenham Looker-On, 6 December 1856. Chetwood returned to Cheltenham in summer 1857, accompanied by her nephew, Edward WilmotChetwode (NLI, MS 49,155/29/20, Tighe, Hamilton \& Howard Papers, Letters of condolence ... on the death of Charles Hamilton of Hamwood, 1857, Edward WilmotChetwode to Charles Hamilton, 20 September 1857). 
of her life, and died on 12 December 1870 in a respectable but modest two-storey house at 14 Montpelier Villas, 'in her ninety-fifth year' ${ }^{37}$ It is worth noting that the Chetwood-Wilmot circle's connections to Cheltenham extended at least as far back as 1806, and that Chetwood's nephew, Edward Wilmot-Chetwode, spent time at 14 Montpelier Villas in $1857 . .^{38}$ The extended family was close, so it is likely that Edward was visiting Chetwood. In all, she may have lived there for at least two decades.

Some indications of Chetwood's personality, interests, and personal relationships can be gleaned from fifteen poems in two Chetwood-Wilmot family albums and commonplace books. Family members and friends wrote poems, riddles, and notes into these albums to celebrate special occasions such as birthdays, to memorialise deceased loved ones, or simply to record favourite poems, songs, riddles, and literary extracts. Never published, Chetwood's poetry merits attention for its place among the personal papers of her sisters-in-law, the travellers and diarists Martha and Katherine Wilmot; for the overwhelmingly commemorative, family-historical nature of her compositions; and, most importantly, for what it reveals about the connections in the Chetwood-Wilmot circle. In other words, it is possible to piece together a picture of her life, and that of her extended circle, through the poems composed by her, her sister, and their father-a record of their births, deaths, wedding anniversaries, and travels.

Alicia Wilmot was born in c.1776 to Captain Edward Wilmot and his wife Martha (née Moore), likely in Glanmire. Captain Wilmot appears to have been well respected in the Cork area, making important connections with landowners like the Mount Cashells and the Penroses. Like Chetwood, Wilmot never married and appears to have been educated by her parents, but nothing more is known of her early life. That Captain Wilmot and his wife took some care with the education of their large family is evident in their literary activities. Their eldest son, Robert, was educated at Trinity College Dublin, where he became acquainted with Robert Emmet.

As the only unmarried member of the family, Alicia Wilmot devoted many years to caring for her parents, with whom she seems to have moved to Clifton near Bristol by 1815; her father was buried there in that year. Incidentally, Chetwood's brother John was also buried at Clifton following his untimely death in $1805 .{ }^{39}$ Correspondence between Wilmot and her elder sister Martha in the

\footnotetext{
37 Western Daily Press, 27 December 1870.

${ }^{38}$ Sarah Curran (Sturgeon) asked Anne Penrose in a letter of 24 October 1806, 'Tell me how the Cheltenham party concluded' (NLI, MS 8327/2, Letters written from the Mediterranean coast and England by Sarah Curran (Mrs Sturgeon) ... 1806-8). NLI, MS 49,155/29/16, Tighe, Hamilton \& Howard Papers. Letters of condolence ... on the death of Charles Hamilton of Hamwood, 1857, Edward Wilmot-Chetwode to Charles Hamilton, 2 October 1857.

${ }^{39}$ Walter G. Strickland, 'The Chetwodes of Woodbrook in the Queen's County', Journal of the Archaeological Society of the County of Kildare 9 (1918-21), 205-26: facing 226.
} 
1820s indicates that Wilmot and her mother divided their time between Bath and Clifton from at least 1815, likely for the sake of the older woman's health. Martha wrote to her mother in 1822 on the subject of her lame leg: 'do you not make use of a Bath Chair? as you are too much accustomed to air and exercise to be well without them!'40 The sisters' correspondence evidences Martha's concern for her mother's health, and its impacts on her younger sister: 'all this falls heavily on you, my dearest Alicia [...] For God's sake have you no friend at Bath who could for a few hours at a time take your place and let you go into the air!'41 After her mother's death, Wilmot appears to have spent some time in Woolwich with her brother Edward and his wife Mary Ann; she then lived at Cheltenham from at least 1833, until her death in 1860. It is therefore likely that Wilmot and Chetwood were for at least a time neighbours, if not living at the same address. ${ }^{42}$

Further aspects of Anna Maria Chetwood and Alicia Wilmot's lives, interests, and personalities can be pieced together from Martha and Katherine Wilmot's detailed records of their travels in France, Italy, and Russia between 1801 and $1829 .{ }^{43}$ Their correspondence indicates that Katherine was on closest terms with Anna Maria Chetwood. Seventeen of Katherine Wilmot's Russian letters survive-Alicia Wilmot copied them into a notebook - and of these, six were addressed to Anna Maria Chetwood. In one letter to Chetwood, Katherine confided, abashed, that she and Martha had attended a bear-baiting; the confession indicates the closeness of the friendship. ${ }^{44}$ There is also evidence that Martha Wilmot maintained at least a patchy correspondence with Chetwood in the $1820 \mathrm{~s} .{ }^{45}$

The Wilmot papers reveal both Chetwood and Alicia Wilmot as educated, intelligent, and curious correspondents-people who were interested in languages and literature, elite and popular culture, and current affairs. Chetwood's father's occupation may have given her an added interest in world religions

\footnotetext{
${ }^{40} \mathrm{H}$. Montgomery Hyde and Edith Stewart (eds), More letters from Martha Wilmot: impressions of Vienna 1819-29 (London, 1935), 188.

${ }_{41}$ Martha Bradford to Alicia Wilmot, 20 April 1824, in Hyde and Stewart, More letters from Martha Wilmot, 213. This article directs the reader to published editions of the Wilmots' writings where possible.

42 In 1833, a 'Miss Chetwood' is recorded as living at 15 Lansdown Crescent, Cheltenham (The Looker-On, 28 August 1833). In 1860, Alicia Wilmot's death is recorded as having occurred on 'Nov. 17, at 27, Lansdown Crescent' (Bath Chronicle and Weekly Gazette, 29 November 1860). A few months later, a probate notice stated that Alicia Wilmot was 'formerly of Bath and late of Cheltenham' (The Times, 21 February 1861). It should not be assumed that the change in house number was not an error, or that the women could not have moved house in the 27 years between the first and last references.

${ }_{43}$ RIA MSS 12L17-25, 12L29-34, 12M18.

${ }_{44}$ RIA MS 12L30, 33-4, Katherine Wilmot to Anna Maria Chetwood, 24 September 1805.

${ }^{45}$ Wilmot received a letter from Chetwood included in an envelope from Alicia Wilmot in 1821 Hyde and Stewart, More letters from Martha Wilmot, 105; see also 118, 200, 202, 244. Martha had a hallucination of a visit from Chetwood while in fever during a visit to Rome in 1821 (More letters from Martha Wilmot, 146).
} 
The authorship of Blue stocking hall and Tales of $m y$ time and philosophies; correspondence between Katherine Wilmot, Anna Maria Chetwood, and Rev. Chetwood included detailed information on the Russian Orthodox and Jewish traditions with which the Wilmots became familiar during their accumulated eight years in Russia. Chetwood requested that Katherine Wilmot keep a journal of her Russian residence, and Katherine teased in return, it is a doubt to me if you will be satisfied unless I go in quest of national curiosities to hang in your brain like a museum'. ${ }^{46}$

On 19 October 1827, Henry Colburn's London publishing house released a new, three-volume epistolary novel titled Blue stocking hall. ${ }^{47}$ Set in Ireland and featuring a cast of characters-Irish and English, urban and rural, male and female, Catholic and Protestant - the book was published during a downturn in the market for Irish fiction, which had enjoyed relative popularity in the period 1800-1820.48 This was also, crucially, on the eve of Catholic Emancipation, after which Irish fiction assumed a new concern with parliamentary independence and, as a result, a decreased role for women authors. ${ }^{49}$ So, by 1831, the author of Blue stocking hall and Tales of my time found that her publisher was unwilling to proceed with a third, similar work because 'The public does not now encourage works of the kind you contemplate as they did two or three years ago, and we have at this moment more manuscripts on hand than we know how to publish with any chance of advantage. ${ }^{50}$ The third novel remains unidentified. ${ }^{51}$

English reviewers received the hefty, 906-page debut novel Blue stocking hall favourably, if not altogether uncritically. A writer for London's Morning Post declared, perhaps over-enthusiastically, that in the book 'the Blues are not only

\footnotetext{
${ }^{46}$ Katherine Wilmot to Anna Chetwood, 1 October 1805, in The Russian journals of Martha and Catherine Wilmot, 199; RIA MS 12L30, Katherine Wilmot to Anna Chetwood, 26 June 1806.

${ }^{47}$ British Library (BL), Publishers' Archives, Richard Bentley \& Son 1829-1898, Mic.B.53/163 Part 2: University of Illinois Collection, Reel 10, Hand list of publications issued from New Burlington Street and Conduit Street 1818-29, compiled by Richard Bentley II, 22.

${ }^{48}$ Connolly, A cultural history of the Irish novel, 6-7.

49 Jacqueline Belanger, 'Some preliminary remarks on the production and reception of fiction relating to Ireland, 1800-1829', Cardiff Corvey: Reading the Romantic Text 4:2 (2000), 1. Available at: http://sites.cardiff.ac.uk/romtextv2/files/2013/02/cc04_n02.pdf (accessed 19 January 2019).

${ }^{50}$ BL, Publishers' Archives, Richard Bentley \& Son 1829-1898, Mic.B.53/137, Part 1: BL Collection, Reel 39, Vol. 81, Letterbooks, 1830-9, 65, Richard Bentley to 'Mrs Wilmot', 12 September 1831.

${ }^{51}$ In 1965, the contents of Woodbrook House-including, it seems, the WilmotChetwode family papers-were sold by public auction. It is therefore possible that evidence confirming the authorship of Blue stocking hall and Tales of my time lies undiscovered in a private collection.
} 
vindicated from the common-place reproaches to which they have been hitherto subjected, but are absolutely placed in a most attractive light and we, therefore, anticipate a complete re-action of fashionable opinion in their favour'. ${ }^{52}$ The reviewer for the Literary Gazette, by contrast, was unconvinced of the book's literary merit, finding 'some good plain sense, as well as excellent principles, inculcated in these pages' but complaining that 'the work cannot be considered as a novel; and the title appears to us to be a complete misnomer. The characters are not Bluestockings, in the common and understood acceptation of the phrase; $[\ldots]$ those who like a moral and virtuous view of society will find it in this Hall. ${ }^{53}$ Maria Edgeworth gave Blue stocking hall a reasonably positive review: 'notwithstanding its horrid title, I have read a great deal of it; and I thought that there was a great deal of good, and of good sense in it'. ${ }^{54}$

Many of the advertisements for the book that were placed in local and national newspapers, presumably worded by an employee of Colburn's publishing house, stated that Blue stocking hall was by 'a lady'. ${ }^{55}$ Within just weeks of publication, the Morning Chronicle appealed for the author's name to be made public, certain that 'were it permitted to be affixed to the work, [it] would at once insure its success and popularity'. ${ }^{56}$ The publication of Tales of my time two years later reinforced the impression of female authorship, with advertisements asserting that the book was 'by the authoress of Blue stocking hall' ${ }^{57}$ In 1830, the Dublin Literary Gazette ran an advertisement for Tales of my time, stating that it was 'By the authoress of "Blue Stocking Hall"". ${ }^{8}$

The second novel brought not only renewed interest in Blue stocking hall - which went into a second edition in the same year-but also yet more praise for the still unknown author. The publisher's advertisement attributed Tales of my time to 'a most exemplary Irish lady of fortune', and hailed its contents as 'admirable examples for the conduct of life in its most chequered state' ${ }^{59}$ To this was added her qualifications as 'deservedly popular' and 'talented and successful' ${ }^{60}$ Her writing, then, became an embodiment of her character against

\footnotetext{
${ }_{52}$ Morning Post, 1 November 1827.

${ }^{53}$ Literary Gazette, and Journal of the Belles Lettres, no. 563 (3 November 1827): 714.

${ }_{54}$ Maria Edgeworth to Mrs Ruxton, 12 Apr. 1829, in Maria Edgeworth, A memoir of Maria Edgeworth, with a selection from her letters by the late Mrs Edgeworth, edited by her children (3 vols, London, 1967), III: 31. Also quoted in Loeber and Stouthamer-Loeber, Guide to Irish fiction 1650-1900, 269-70.

55 For example, Morning Chronicle, 6 November 1827; Manchester Courier and Lancashire General Advertiser, 27 October 1827; Morning Post, 6 November 1827.

56 Morning Chronicle, 6 November 1827.

57 The Standard, 14 October 1829; Morning Post, 22 October 1829; The Standard, 24 October 1829; Morning Chronicle, 6 November 1829; Cheltenham Chronicle, 21 January 1830 .

58 Dublin Literary Gazette, 30 January 1830.

59 Advertisement in [John Banim and Michael Banim], The denounced (2 vols, New York, 1830), I: 312.

${ }^{60}$ The Standard, 14 October and 24 October 1829.
} 
the backdrop of the 'degrading options' available to the woman writer of the nineteenth century (anonymity, self-positioning as 'inferior', or rebellion). ${ }^{61}$ The author of Blue stocking hall and Tales of my time, with her unwaveringly moralistic tone, seems to have been keenly aware of the ways in which publishing as a woman might invite criticism, even with the abatement of moral concerns about women reading and writing novels that was under way from the $1810 \mathrm{~s} .{ }^{62}$

It is clear, therefore, that in 1827-30 it was widely accepted that Blue stocking hall and Tales of my time were by a female author. But if female authorship was asserted almost immediately on their publication, how did they come to be attributed to the English writer and Unitarian minister William Pitt Scargill (1787-1836) ${ }^{63}$ A contemporary review of Scargill's The usurer's daughter (1832) speculated that he might also be the author of Blue stocking hall and Truckleborough hall (1827), but acknowledged that this 'may be wrong' as the only indication was 'the internal evidence of a family resemblance'. Nonetheless, the reviewer praised the 'very great' improvement in the author's prose since the first book, by which they meant either Blue stocking hall or Penelope (1828), depending on just how many novels they wished to claim for Scargill's name. ${ }^{64}$ Even the reviewer for the Ladies' Magazine, who praised Blue stocking hall's championing of female intellectualism, took for granted the novel's male authorship. ${ }^{65}$ The enduring misattribution of Blue stocking hall and Tales of my time can only be untangled and understood by being traced through a number of channels, the next of which is that of the Cork antiquary John Windele.

In 1839, Windele published his Historical and descriptive notices of the city of Cork, an important work that would run to at least five editions during his lifetime. It was here that Chetwood was first publicly identified as the author of Blue stocking hall. Despite Windele's intimate knowledge of the city of Cork and its environs, his work was not error-free, and his short account of Chetwood's accomplishments introduced mistakes to her biography. The authority granted to Windele as a local expert, and his repetition of his assertions in an 1862 article, have ensured the perpetuation of these errors. ${ }^{66}$

\footnotetext{
${ }^{61}$ Sandra M. Gilbert and Susan Gubar, The madwoman in the attic: the woman writer and the nineteenth-century literary imagination ([1979] 2nd edn, New Haven, CT, 2000), 64.

${ }^{62}$ Jacqueline Pearson, Women's reading in Britain 1750-1835: a dangerous recreation (Cambridge, 1999), 197.

${ }^{63}$ Trusted reference works such as the $O D N B$ continue to attribute Blue stocking hall to Scargill's pen. Alexander Gordon, 'Scargill, William Pitt (1787-1836)', rev. Clare L. Taylor, $O D N B$, available at: http://www.oxforddnb.com/view/article/24781 (accessed 5 November 2017). The same attributions are made in Peter Garside, James Raven, and Rainer Schöwerling (eds), The English novel 1770-1829: a bibliographical survey of prose fiction published in the British Isles (Oxford, 2000), II, 650, 692.

${ }^{64}$ Literary Gazette, 26 November 1831. The article referred to Scargill as 'Scarlett'.

${ }^{65}$ Ladies'Magazine, March 1828.

${ }^{66}$ [John Windele], 'Forgotten novels', Dublin University Magazine 59 (June 1862), 339-51, 685-99, 694.
} 
Miss Chetwode-This lady, the daughter of the late Rev. Mr. Chetwode of Glanmire in the vicinity of Cork, accompanied in early life from that city, and lived at Moscow with the celebrated Princess Dashkoff, one of the principal instruments in the assassination of the Czar Peter III and transference of the Russian Crown to Catherine II. From the princess she enjoys an annuity, and returned to England after her death. She has written "Blue Stocking Hall," "Snugborough," and other novels. ${ }^{67}$

There are several important errors in Windele's short account of Chetwood's life, quoted here in full. First, he incorrectly renders her surname as 'Chetwode', which was a title granted to her nephew, Edward Wilmot-Chetwode (1801-74) by royal licence when he succeeded his uncle, Jonathan Chetwood (1757-1839) to the family seat at Woodbrook, Portarlington. The rendition 'Chetwode' only applies to that branch of the family and is an important expression of their change in fortune as they transitioned within a generation from being the comfortable offspring of a country minister to the titled custodians of a 'big house' and estate.

The second, and more serious, error is Windele's false assertion that Chetwood travelled to Russia and resided with Princess Dashkova. Chetwood made no such journey - indeed, there is no evidence that she ever left Britain and Ireland. Windele's short biography in fact conflates Chetwood's life story with that of her friends and sisters-in-law, Martha and Katherine Wilmot, who spent years in Russia and were among Dashkova's closest companions in her later years. Windele's false assertion that Chetwood travelled to Russia has, unfortunately, been repeated in modern scholarship. ${ }^{68}$ Three points require clarification in relation to this. First, the 'Anna' so often referred to by Martha Wilmot in her Russian letters and diaries was not Anna Maria Chetwood but Anna Petrovna Isleniev, Dashkova's niece and companion. Secondly, both Martha and Katherine Wilmot maintained a regular correspondence with Chetwood during their time in Russia, keeping her abreast of their experiences and impressions of a country she would never visit. Thirdly, it was Martha Wilmot and not Chetwood who received substantial gifts of money-but never an annuity-from Dashkova.

Finally, Windele also claims that Chetwood moved to England after Dashkova's death (1810), whereas she may have remained in Glanmire until at least 1826. In October of that year, Martha Wilmot wrote to Alicia Wilmot: 'when the Chetwoods quit Glanmire how dark, instead of bright, will be

\footnotetext{
${ }^{67}$ John Windele, Historical and descriptive notices of the city of Cork and its vicinity (Cork, 1839), 130.

68 Windele's error is repeated in Loeber and Stouthamer-Loeber, Guide to Irish fiction 1650-1900, 268-71; Loeber and Stouthamer-Loeber, in DIB; Jason King, 'Prefiguring the peaceable kingdom: the construction of counter-revolutionary sentiment in IrishCanadian romantic verse and prose', Canadian Journal of Irish Studies 31:1 (2005), 38-44: 40 .
} 
its recollection and association to our feelings' ${ }^{69}$ In Windele's account, then, the members of this circle of writing women appear to have entered into local Cork legend, their identities and life stories conflated and intertwined to form one striking persona. The Chetwood and Wilmot families were neighbours, and were connected by intergenerational ties of friendship and marriage. It can only be surmised that Windele, drawing on local information for events that had occurred up to three decades previously, either was misinformed or misunderstood the information with which he was provided, leading him to integrate three women's remarkable life stories into just one, and rendering him an unreliable source for any aspect of Chetwood's life. The second title with which Windele credits Chetwood's pen has never been discovered. Loeber and Stouthamer-Loeber surmised that by 'Snugborough' Windele may have meant Truckleborough hall (which appears to have been by Scargill) and while this connection seems strained, I can offer no other credible explanation for his reference to an apparently non-existent book.

Fast-forward to the 1890s, when Richard Bentley the younger(1854-1936), grandson of the founder of Colburn and Bentley's, began the mammoth task of compiling a catalogue of every title that the company-under a variety of company names, and with and without Henry Colburn - had brought to fruition since its establishment in 1819 . He trawled painstakingly through the company records, indexing extant correspondence, publishing agreements, records of copyright and royalties, writing samples, and fragments of drafts, to produce lists of its 'principal publications' for the years $1829-1898 .^{70}$ His manuscript notes and worksheets show how Barbarina Brand and Rev. William Pitt Scargill became associated with the novels Blue stocking hall and Tales of my time.

Barbarina (Wilmot) Brand, Lady Dacre (1768-1854) was a celebrated writer who maintained a friendly correspondence with Richard Bentley the elder in the months prior to her death. ${ }^{71}$ It is, therefore, perhaps understandable that when Richard Bentley the younger encountered a letter of 1831 from his grandfather to a 'Mrs Wilmot', he may have thought of what must have seemed the most obvious person-Brand. Bentley's notes confirm that he consulted the Dictionary of national biography, which had been published in 1885 and contains an entry on Brand. Born Barbarina Ogle, she was married to Valentine Henry Wilmot (d. 1819) prior to her marriage in December 1819 to Thomas Brand, Baron Dacre. It seems extremely unlikely that someone of her social standing would have been addressed in 1831 by a name by which she had not been known for twelve years. The friendly tone of the later correspondence

\footnotetext{
${ }^{69}$ Martha Bradford (née Wilmot) to Alicia Wilmot, 19 October 1826, in Hyde and Stewart, More letters from Martha Wilmot, 251.

${ }^{70}$ A list of the principal publications issued from New Burlington Street 1829-1898 (8 vols, London, 1893-1920).

${ }^{71}$ Nine short letters for the period c.1854-5, from Dacre to Bentley, survive in BL, Publishers' Archives, Richard Bentley \& Son 1829-1898, Mic.B.53/179, Part 2: University of Illinois Collection, Reel 26: Correspondence Co-Da.
} 
between Brand and Bentley confirms that they were well acquainted, further dispelling any suggestion that his 1831 letter could have been intended for her, as it is highly unlikely that Bentley would have employed her former name. Finally, Blue stocking hall and Tales of my time are generically unrelated to Brand's other publications, as she was best known as a poet and dramatist. The question then arises - could the Bentley letter have been intended for her daughter, Arabella Wilmot (1796-1839)? Arabella had, after all, published two anonymous novels, Recollections of a chaperon (1831) and Tales of the peerage and peasantry (1835). However, she married Rev. Frederick Sullivan in 1821, so it again seems unlikely that she could have been addressed by the surname 'Wilmot' ten years later.

Aside from these details, the most crucial piece of evidence in the 1831 letter is the address scribbled in the top left-hand corner of the page: 'Woodbrook, Portarlington, Ireland'. Neither Brand nor her daughter had any known connection with Woodbrook at any stage in her life. Furthermore, the alert reader might have recalled a brief reference in 1844 to Blue stocking hall's 'most accomplished and amiable authoress' as 'Mrs Wilmot of Clifton'72 in Bentley's Miscellany - another location with which Brand had no connection. Richard Bentley the younger's hurried pencil scrawl in the company's record books, then, was an error, probably the combined result of the scale of the task of identifying long-dead and anonymous authors from incomplete records and the ingrained assumption that only 'exceptional' women like Brand and her daughter wrote and published. But who, then, was 'Mrs Wilmot'? We return to the families that were connected with Woodbrook and Clifton - the Wilmots and Chetwoods.

There are few contenders in the extended family tree for the title of 'Mrs Wilmot' in 1831. Katherine Wilmot died in Paris in 1824 (where she had lived since at least 1821). ${ }^{73}$ Martha Wilmot's 1812 marriage to Rev. William Bradford (1780-1857), and her residence at Storrington, Sussex by 1831, exclude herall but one of the younger Wilmot sisters had also married. This leaves three possible candidates. The first is Alicia Wilmot who, as outlined above, moved from Glanmire to Clifton or Bath with her parents before 1815 and, as their only unmarried daughter, cared devotedly for both of them. It may be of further significance that the administrator of her will was based in Portarlington, demonstrating that she had a deep relationship with the place. The second is Elizabeth Wilmot (née Chetwood) - a less likely prospect because she only ever lived in Cork - and the third candidate is Elizabeth's daughter-in-law Lady Janet Erskine, who married Edward Wilmot in April 1830; but the pair's main residence was at Woodbrook only from $1839 .{ }^{74}$

Further complicating evidence is found in private correspondence between Alicia and Martha Wilmot. On 12 December 1827, less than two months

\footnotetext{
72 'Eton scenes and Eton men, by the author of "Doctor Hookwell"', Bentley's Miscellany 16 (1844), 38.

${ }^{73}$ See Martha's grief at the news of Katherine's death, expressed in a letter to Alicia on 20 April 1824, in More letters, 210-14.

${ }^{74}$ Derby Mercury, 5 May 1830.
} 
Blue stocking hall and Tales of $m y$ time in the context of the ChetwoodWilmot archive after the book was published, the Vienna resident wrote in jest to Alicia, saying of their sixteen-year-old nephew Edward (son of Robert Wilmot and Elizabeth Chetwood), 'if [he] will not follow up a profession, he had much better be on the look out for a rich wife and woo her with Verses from blue stocking hall!! ${ }^{75}$ It seems unlikely that Martha stumbled across this English-language novel in Vienna within weeks of its publication; it also seems an unlikely chance reference in a crowded literary marketplace. This reference is therefore strong circumstantial evidence linking Alicia Wilmot to Blue stocking hall. However, H.M. Hyde's 1935 edition of Martha Wilmot's Vienna letters grants authorship of the novel to Anna Maria's sister, Elizabeth. While Elizabeth was a prolific (if unpublished) poet, it is unlikely that she authored the novels, not least because it seems that she only ever resided in Cork. It is indeed true that a reader of Blue stocking hall would find thematic similarities between the novel and her poem 'Written in a moment of great depression', which contains the lines: 'Society! thou vain, deceitful Name! / The Glass of Idleness-The Trap of Fame [...]. ${ }^{96}$ Hyde understandably interpreted Martha Wilmot's remark in terms of the young man's parentage - but failed to consider it within the context of a tightly knit extended family who remained in close contact despite long periods of separation. During Martha Wilmot's residence in Vienna (1819-29), she and Alicia corresponded regularly, writing affectionately with news of family and mutual acquaintances, and maintaining a pattern that had been established over 20 years earlier during Martha's five-year residence in Russia.

A final possibility is that Anna Maria Chetwood and Alicia Wilmot collaborated on Blue stocking hall and Tales of my time, given the uncanny parallels in their lives - both had literary leanings, both died unmarried, both seem to have acted as carers for older relatives - and the striking proximity of their residences in later life. There is evidence that the pair were in close contact in the 1820s. For example, Alicia Wilmot included a letter from Anna Maria Chetwood in a packet of letters to Martha Wilmot in 1821, and Martha communicated her continued affection for Anna Maria Chetwood in a letter to Alicia Wilmot in 1823: 'Dear Anna Chetwood! the thoughts of her does me good, tho' we never write to each other. ${ }^{77}$ Anna Maria and Alicia certainly appear to have maintained a close friendship.

The Chetwood family had a noteworthy literary heritage, and one that is all the more striking when Blue stocking hall and Tales of my time are considered alongside the dozens of unpublished poems composed by Anna Maria Chetwood, her

${ }^{75}$ Martha Bradford to Alicia Wilmot, 12 December 1827, in More letters, ed. Hyde and Stewart, 308, 308n.

${ }_{76}$ [A collection of poetry], compiled by Eliza Wilmot, 1814-22, 8741, Benjamin Iveagh Library, Farmleigh, 140.

${ }^{77}$ Hyde and Stewart, More letters from Martha Wilmot, 105, 202. 
sister Elizabeth, and their father. Chetwood's great-grandfather, Knightly Chetwode of Woodbrook, was a friend of Jonathan Swift, and it has been suggested that the Chetwoods may have claimed distant relatives in Maria Edgeworth and the mid-eighteenth-century playwright, novelist, and publisher William Rufus Chetwood (d. 1766) ${ }^{78}$ Chetwood's father wrote, but never published-with the exception of his posthumously published epitaph for Sarah Curran-many small pieces of prose and verse, and a nineteenth-century antiquary described him as having been 'of a highly literary turn of mind' ${ }^{79} \mathrm{He}$ was acquainted with Thomas Southwell and with Bishop George Berkeley, and was sufficiently acquainted with the lawyer and literary scholar Edmond Malone to employ the diminutive 'Ned' in correspondence. ${ }^{80}$ Dozens of Elizabeth Wilmot's (née Chetwood) unpublished poems survive in (at least) six manuscript albums preserved in the Royal Irish Academy, Farmleigh House, and Senate House Library. ${ }^{81}$ Finally, Chetwood's grandniece, Alice Wilmot-Chetwode, continued the family literary tradition, publishing English translations of several works of French fiction and non-fiction. ${ }^{82}$

Literary composition was clearly highly valued and performed important functions in the Chetwood household. For Rev. John Chetwood, literary pursuits seem to have provided a welcome distraction from mundane rural Irish life - the same dull image, incidentally, as expressed by Blue stocking hall's male protagonist, young Arthur Howard, when he first arrives in Kerry from England. In 1765, not long after his removal from England to Cork, John Chetwood wrote to his friend Edward Malone:

\footnotetext{
78 John Bernard Burke, A genealogical and heraldic dictionary of the landed gentry of Great Britain and Ireland (London, 1847), I: 213; Loeber and Stouthamer-Loeber, Guide to Irish fiction 1650-1900, 268, 271.

${ }^{79}$ Brady, Clerical and parochial records of Cork, Cloyne, and Ross, I: 52.

${ }^{80}$ Letters from Chetwood to Malone in the 1760s are published in James Prior, Life of Edmond Malone, editor of Shakespeare, with selections from his manuscript anecdotes (London, 1860), 14-35. In a letter of 26 April 1808, Malone promises to send a copy of The tempest to Chetwood in Cork (RIA, MS 12R44/165).

${ }^{81}$ Senate House Library, University of London, MS 704, Commonplace book [...] containing copies of poems by various authors, including Mrs R. Wilmot, Rev. John Chetwood, and Edward Wilmot, [early 19th cent.], ff. 12r, 114r; Benjamin Iveagh Library, Farmleigh, 871, [A collection of poetry], compiled by Alicia Wilmot, 1805; Benjamin Iveagh Library, Farmleigh, 8741, [A collection of poetry], compiled by Eliza Wilmot, 1814-22; RIA, Wilmot Papers, MS 12L25 (1), E.R. Dashkova, Martha Wilmot [and others], Poems and miscellaneous notes, 1803-7, unpaginated folios; RIA, Wilmot Papers, MS 12L29 (1), Martha Wilmot, Poems, letters, extracts and notes, 1803-7; RIA, Wilmot Papers, MS 12L29 (3), E.R. Dashkova, Martha Wilmot [and others], Poems, letters, extracts and notes, 1803-7.

${ }^{82}$ See Michèla Milan, 'Found in translation: Franco-Irish translation relationships in nineteenth-century Ireland', PhD thesis, Dublin City University, 2013, 176-7. Available at: http://doras.dcu.ie/17753/1/PhD_Thesis_Michele_Milan.pdf (accessed 11 September 2017).
} 
I should be highly obliged to you if you would give me an account of anything that appears in the literary world, worth notice. Books of the highest reputation may be read over half the globe before the fame of them is published in this unilluminated region. This is no small loss to me, who have a great deal of time to devote to study. It obliges me to employ my attention very frequently upon productions from which it is difficult to glean any useful knowledge amidst rude heaps of barbarous language and uninteresting events. ${ }^{83}$

While becoming established in rural Munster, John Chetwood oscillated between contentment and boredom. At times he felt 'pleased with [his] situation' and even, in the summer of 1766, began to 'like the people of the country rather more than [he] did'. However, by February 1768 his negative feelings resurfaced during a spell at Skibbereen, and he complained, 'I am sick of solitude and a sequestered rural life already. ${ }^{, 84}$ No such personal observations from Chetwood seem to have survived.

Chetwood's ad-hoc compilations reveal the strength of her female friendships and of the extended familial bonds - dynamics that are mirrored in the fictional Douglas family of Blue stocking hall. A letter from Emily Douglas to her friend Julia Sandford reflects on their relationship, maintained over distance by correspondence: '[...] your visit at Glenalta, [...] the most joyful period of my existence. In addition to all the blessings of my daily life, I had then the enlivening influence of your presence. [...] while you were here, all seemed "gold and green"' (I: 13). Six of Chetwood's extant poetic compositions are eulogies, indicating that family and friends regarded her as competent in that genre. These include two epitaphs for her friend Anne Christian, Baroness Hompesch (1775-1803), one of which was 'written at the request of the Baron' ${ }^{85}$ Hompesch's husband raised a corps of mounted rifles that was engaged in Ireland in 1798-1802. ${ }^{86}$ It was during this time that she became acquainted with the Wilmots and Chetwood; Martha Wilmot copied a French song into her album, with a note that it had been given to her by the Baroness in Cork in $1801 .{ }^{87}$ The Baron's request for a literary tribute from Chetwood was both a compliment to her talent and a testimony to the women's friendship. 'A first poetical attempt

\footnotetext{
83 John Chetwood to Edmond Malone, November 1765, in Prior, Life of Edmond Malone, editor of Shakespeare, 19-20.

${ }^{84}$ John Chetwood to Edmond Malone, August 1766, February 1768, in Prior, Life of Edmond Malone, editor of Shakespeare, 22, 31.

${ }^{85}$ RIA, MS 12L25, Dashkova and Wilmot [and others], Poems and miscellaneous notes, 1803-7.

${ }^{86}$ René Chartrand, Émigré and foreign troops in British service (1): 1793-1802 (New York, 2013), 17.

${ }^{87}$ RIA, MS 12L25, Dashkova and Wilmot [and others], Poems and miscellaneous notes, 1803-7.
} 
on the death of a beloved brother' commemorates Chetwood's brother John (1779-1805), who was a captain in the British Army. ${ }^{88}$ This poem must also have held special significance for the Wilmots, whose youngest brother, Charles, died in service in 1802. 'To the memory of Dr Currie' commemorates James Currie, biographer of Robert Burns ${ }^{89}$ the Scottish poet was a particular object of Wilmot admiration, and the same can likely be said of Chetwood. Currie spent some time at Clifton, near Bristol - a place with which both the Wilmot and Chetwood families had connections. The precise details remain unclear, but members of both families seem to have relocated to the genteel neighbourhood in the first decade of the nineteenth century. Chetwood's sixth elegy was to the memory of Robert Emmet.

\section{Conclusion}

Contemporary audiences received Blue stocking hall and Tales of my time with varying degrees of praise and criticism. In the case of Blue stocking hall, the focus rested almost exclusively on gender politics, with virtually no comment on the book's exploration of Anglo-Irish relations. Advertisements described Blue stocking hall as 'an agreeable contrast to the generality of works of fiction. It is designed to inculcate, in the shape of a pleasing fiction, the various duties of domestic life [...] It appears to have been the intention of the authoress to produce a work which every mother should possess, and which every daughter should read. ${ }^{90}$ The publisher, Colburn and Bentley, presented and promoted the work as a progressive - if belated - vindication of much-maligned 'bluestockings'. The Gentleman's Magazine found that, 'In spite of its very unpromising title [...] its objects are laudable, its opinions sensible, and its style lively or forcible, as occasion may require.' However, the same reviewer also found that 'The incidents are few, and in fact it has no pretensions to the character of a novel, for which it may have been mistaken', yet it was 'entertaining and useful'. ${ }^{91}$ Blue stocking hall has, on occasion, been referenced by other writers and later literary historians. One mid-nineteenth-century account of Boston facetiously referred to a spinning mill - whose female workers were covered in blue dye - as 'this "Blue Stocking Hall". ${ }^{92}$ In 1915, the critic Allene Gregory blasted Blue stocking hall as 'the contribution of the Reaction [to the French Revolution] at its worst'

\footnotetext{
${ }^{88}$ Bernard Burke, A genealogical and heraldic dictionary of the landed gentry of Great Britain and Ireland for 1852: comprising particulars of upwards of 100,000 individuals (2 vols, London, 1852), I: 213.

${ }^{89}$ Margaret de Lacy, 'Currie, James (1756-1805)', ODNB, available at: https://doi. org/10.1093/ref:odnb/6954 (accessed 15 January 2019).

90 Advertisement in [Banim and Banim], The denounced 1: 312; Edinburgh Literary Journal, 13 February 1830.

91 Gentleman's Magazine, April 1828.

92 J.R. Dix, Local loiterings: and visits in the vicinity of Boston by a looker-on (Boston, 1845), 76.
} 
and contrasted it with Wollstonecraft's Vindication of the rights of woman. ${ }^{93}$ More recent studies refer to the novel's support of female education, placing it, perhaps not wholly justifiably, alongside early feminist contributions. ${ }^{94}$

These attempts to ascribe motives to an unknown author highlight one of the broader issues raised by Blue stocking hall and Tales of my time, that is, the challenges that anonymous novels present to literary criticism and historicism. In an attempt to resolve this difficulty, anonymity itself is commonly explained as the expression of particular motives, such as modesty, fear, or shame. ${ }^{95}$ However, the decision to publish anonymously loses force when we remember that, in the period, anonymity was common, and that in this case there is no evidence that anonymity was an autonomous authorial decision.

Blue stocking hall and Tales of my time also demand that the reader consider the extent to which the motives of a novel's internal characters can be understood as in alignment with those of the author. ${ }^{96}$ The recovery of Alicia Wilmot and Anna Maria Chetwood's biographies and writings responds, in many ways, to Claire Connolly's call for a 'recovery of the political meanings of women's role as agents of active and politicised forms of sociability in the heyday of the Irish romantic novel' ${ }^{97}$ Chetwood has been described as 'one of the early Irish women fiction writers to deal with politics and improvements of the place of women in society', based on Blue stocking hall's advocacy of education for women and the lower classes, and the characters' discussions of contemporary literature, religion, and politics. ${ }^{98}$ However, the second volume of Tales of my time, titled The young reformers, has been described as counter-revolutionary and anti-Jacobin, with the focus 'less on the resolution of tension or engendering sympathy between the English and Irish than the retrenchment of a sense of political acquiescence, formal religious observance, and conservative reaction against the threat of revolutionary violence under the benign mantle of British

\footnotetext{
${ }^{93}$ Allene Gregory, The French revolution and the English novel (New York, 1915), 265-9; contrast with the brief but more positive comments in Coenraad Bart Anne Proper, Social elements in English prose fiction between 1700 and 1832 (Amsterdam, 1929) and Wanda F. Neff, Victorian working women: an historical and literary study of women in British industries and professions 1832-1850 (1929; reprint, London, 1966).

${ }^{94}$ These include Susan Phinney Conrad, Perish the thought: intellectual women in romantic America, 1830-1860 (Oxford, 1976) and Anne Kostelanetz Mellor, Romanticism and feminism (Bloomington, IN, 1988).

${ }^{95}$ Mark Vareschi, 'Motive, intention, anonymity, and Evelina', ELH 82:4 (2015), 1135-58: 1135,1140

${ }_{96}$ Mark Vareschi insists on the separation of motives of author and characters ('Motive, intention, anonymity, and Evelina', 1143), while Catherine Gallagher reads Frances Burney's characters in Evelina (1778), for example, as enactments of the author's intentions - 'the emphatic anonymity of Evelina's author and the namelessness of Evelina as author' (emphasis in original) - in Nobody's story: the vanishing acts of women writers in the marketplace, 1670-1820 (Berkeley, CA, 1994), p. 211.

${ }^{97}$ Connolly, Cultural history of the Irish novel, 1790-1829, 109.

${ }_{98}$ Loeber and Stouthamer-Loeber, Guide to Irish fiction 1650-1900, 269.
} 
imperial authority'. ${ }^{99}$ Can either interpretation be considered representative of the author's personal views? It certainly does not follow that an advocate for progress in women's education would possess radical political views. However, the scandal surrounding Margaret King, Lady Mount Cashell, who gained infamy for abandoning her husband and children to live with her Irish lover in Italy, cannot have escaped Anna Maria Chetwood or Alicia Wilmot's notice. They were all neighbours, and Katherine Wilmot was a close friend of King's. ${ }^{100}$ Indeed, this may have influenced the particular brand of conservatism communicated through both novels, which married a belief in educational equality for the sexes with concern for the maintenance of the family unit.

The range of available evidence in relation to the question of the authorship of Blue stocking hall and Tales of my time is relatively limited, and is mostly circumstantial. While it is now certain that William Pitt Scargill did not author these novels, direct evidence to ascertain positively the true author's identity is lacking. The author's long-maintained anonymity robbed the corpus of Irish women's writing of at least two novels that may have-if authored by Anna Maria Chetwood or Elizabeth Wilmot (née Chetwood) - been accompanied by dozens of unpublished poems that, as a corpus of work, say much about the political, literary, and aesthetic concerns of a predominantly rural but internationally well-connected group of nineteenth-century Irish writing women, andin the case of Anna Maria Chetwood and Alicia Wilmot - members of the Irish literary diaspora.

${ }_{99}$ King, 'Prefiguring the peaceable kingdom', 38.

100 Janet Todd, Rebel daughters: Ireland in conflict 1798 (London, 2003), 326. 